\title{
Correction to: Amyloid- $\beta$ misfolding as a plasma biomarker indicates risk for future clinical Alzheimer's disease in individuals with subjective cognitive decline
}

\author{
Julia Stockmann ${ }^{1,2}$, Inge M. W. Verberk ${ }^{3,4}$, Nina Timmesfeld ${ }^{5}$, Robin Denz ${ }^{5}$, Brian Budde ${ }^{1,2}$, Julia Lange-Leifhelm ${ }^{1,2}$,
} Philip Scheltens ${ }^{4}$, Wiesje M. van der Flier ${ }^{4}$, Andreas Nabers ${ }^{1,2}$, Charlotte E. Teunissen ${ }^{3}$ and Klaus Gerwert ${ }^{1,2^{*}}$

\section{Correction to: Alz Res Ther (2020) 12:169 \\ https://doi.org/10.1186/s13195-020-00738-8}

Following publication of the original article [1], the authors noticed that the published figures have errors which was occurred during processing of the figures in production team.

1) fonts are shifted (Figure 1)

2) colors are not displayed (Figure 2, open circles should be colored)

3) labelling is incorrect (Figure 4, "Afl" should be "Aß", Supplementary Figures "D Absorbance" should be " $\Delta$ absorbance" $(\Delta=$ delta $))$

The correct Figures 1,2 and 4 are shown below. The original article [1] has been updated.

\footnotetext{
Author details

${ }^{1}$ Competence Center for Biospectroscopy, Center for Protein Diagnostics (PRODI), Ruhr-University Bochum, Bochum, Germany. ${ }^{2}$ Department of Biophysics, Faculty of Biology and Biotechnology, Ruhr University Bochum, Bochum, Germany. ${ }^{3}$ Department of Clinical Chemistry, Neurochemistry Laboratory, Amsterdam Neuroscience, Vrije Universiteit Amsterdam, Amsterdam UMC, Amsterdam, The Netherlands. ${ }^{4}$ Department of Neurology, Alzheimer Center Amsterdam, Amsterdam Neuroscience, Vrije Universiteit
}

The original article can be found online at https://doi.org/10.1186/s13195020-00738-8

* Correspondence: klaus.gerwert@rub.de

${ }^{1}$ Competence Center for Biospectroscopy, Center for Protein Diagnostics (PRODI), Ruhr-University Bochum, Bochum, Germany

${ }^{2}$ Department of Biophysics, Faculty of Biology and Biotechnology, Ruhr University Bochum, Bochum, Germany

Full list of author information is available at the end of the article
Amsterdam, Amsterdam UMC, Amsterdam, The Netherlands. ${ }^{5}$ Department of Medical Informatics, Biometry and Epidemiology, Ruhr University Bochum, Bochum, Germany.

Published online: 15 January 2021

\section{Reference}

1. Stockmann J, Verberk IMW, Timmesfeld N, et al. Amyloid- $\beta$ misfolding as a plasma biomarker indicates risk for future clinical Alzheimer's disease in individuals with subjective cognitive decline. Alz Res Ther. 2020;12:169 https://doi.org/10.1186/s13195-020-00738-8

(c) The Author(s). 2021 Open Access This article is licensed under a Creative Commons Attribution 4.0 International License, which permits use, sharing, adaptation, distribution and reproduction in any medium or format, as long as you give appropriate credit to the original author(s) and the source, provide a link to the Creative Commons licence, and indicate if changes were made. The images or other third party material in this article are included in the article's Creative Commons licence, unless indicated otherwise in a credit line to the material. If material is not included in the article's Creative Commons licence and your intended use is not permitted by statutory regulation or exceeds the permitted use, you will need to obtain permission directly from the copyright holder. To view a copy of this licence, visit http://creativecommons.org/licenses/by/4.0/ The Creative Commons Public Domain Dedication waiver (http://creativecommons.org/publicdomain/zero/1.0/) applies to the data made available in this article, unless otherwise stated in a credit line to the data. 

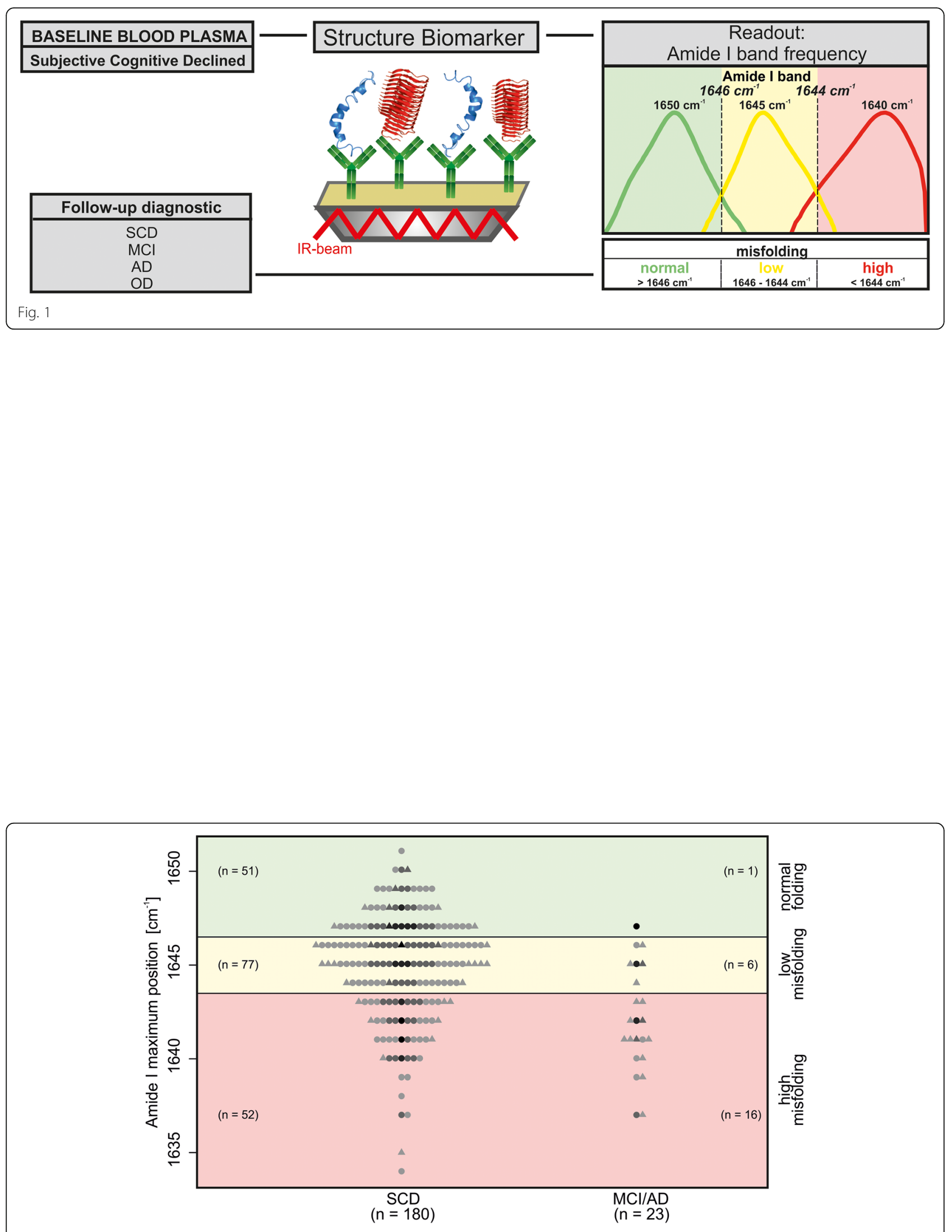
a)
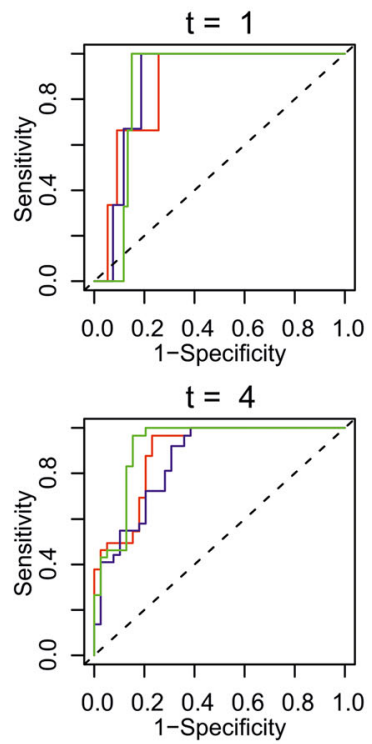

$\mathrm{t}=2$

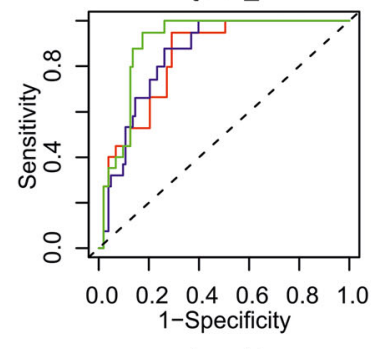

$t=5$

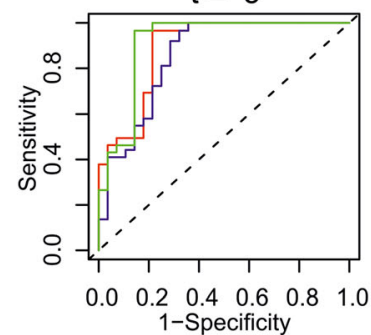

$t=3$

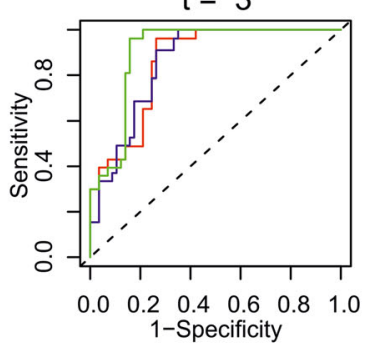

$t=6$

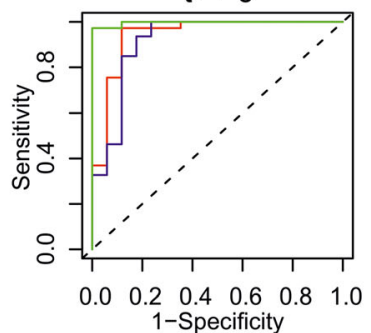

b)

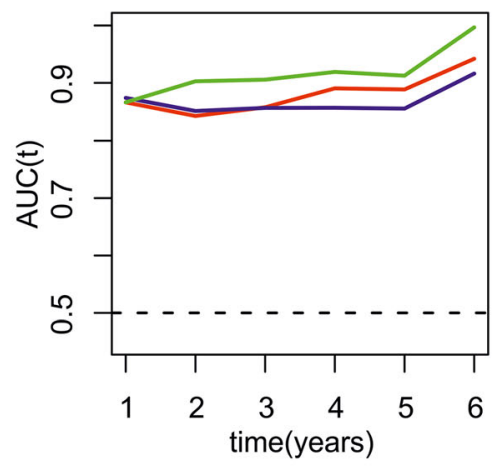

c)

\begin{tabular}{|c|c|c|c|c|c|c|}
\hline & \multicolumn{2}{|c|}{ model 1 (Aß misfolding) } & model 2 (Aß42/40 ratio & \multicolumn{2}{c|}{ Full model } \\
\hline time & AUC & $95 \%-\mathrm{Cl}$ & AUC & $95 \%-\mathrm{Cl}$ & AUC & $95 \%-\mathrm{Cl}$ \\
\hline $\mathrm{t}=1$ & 0.8660 & {$[0.76,0.97]$} & 0.8738 & {$[0.81,0.94]$} & 0.8662 & {$[0.82,0.92]$} \\
\hline $\mathrm{t}=2$ & 0.8424 & {$[0.76,0.92]$} & 0.8510 & {$[0.78,0.93]$} & 0.9028 & {$[0.85,0.96]$} \\
\hline $\mathrm{t}=3$ & 0.8575 & {$[0.77,0.94]$} & 0.8564 & {$[0.77,0.94]$} & 0.9056 & {$[0.84,0.97]$} \\
\hline $\mathrm{t}=4$ & 0.8905 & {$[0.81,0.97]$} & 0.8566 & {$[0.76,0.95]$} & 0.9191 & {$[0.85,0.99]$} \\
\hline $\mathrm{t}=5$ & 0.8886 & {$[0.80,0.98]$} & 0.8552 & {$[0.75,0.96]$} & 0.9126 & {$[0.83,1.00]$} \\
\hline $\mathrm{t}=6$ & 0.9420 & {$[0.86,1.00]$} & 0.9162 & {$[0.82,1.00]$} & 0.9968 & {$[0.99,1.00]$} \\
\hline
\end{tabular}

